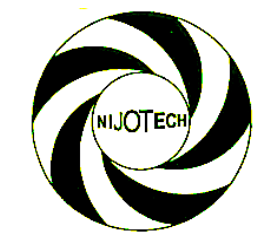

Nigerian Journal of Technology (NIJOTECH)

Vol. 39, No. 1, January 2020, pp. 315 - 324

Copyright@ Faculty of Engineering, University of Nigeria, Nsukka,

Print ISSN: 0331-8443, Electronic ISSN: 2467-8821

www.nijotech.com

http://dx.doi.org/10.4314/njt.v39i1.35

\title{
TEMPORAL VARIATION OF GROUNDWATER RESOURCES IN ILESA WEST LOCAL GOVERNMENT, OSUN STATE NIGERIA
}

\author{
O. O. Fadipe ${ }^{1, *}$ and K. T. Oladepo ${ }^{2}$ \\ 1, Department of Civil Engineering, Osun State University, Osogbo, Osun State, NIGERIA \\ 2, Department of Civil Engineering, Obafemi Awolowo University, Ile-IfE, Osun STATE, NIGERIA \\ E-mail addresses: 1 olayemifadipe@yahoo.com, 2 koladepo1@yahoo.com
}

\begin{abstract}
The study was carried out to investigate the different groundwater resources and to generate the temporal differences over the different seasons in Ilesa West Local Government, Osun State, Nigeria. The LGA has not been provided with municipal pipe-borne water supply for over 30 years, hence they are exclusively using groundwater in form of boreholes, dugwells and springs. The physico- chemical and heavy metal parameters were determined over a period of one year covering the rainy and dry seasons. A total of 69 drinking water points which comprises of 63 dugwells, 5 boreholes and 1 spring were used for the study and they were selected to represent the built-up part of the entire study area adequately. Parameters analysed were pH, electrical conductivity (EC), temperature, total dissolved solids (TDS), chloride, sulphate, nitrate, sodium, potassium (K), calcium, magnesium, hardness, alkalinity, bicarbonate using standard methods. Analysis of heavy metals ( $F$, $\mathrm{Cr}$ ) was carried out with atomic absorption spectrophotometer (AAS) and microbiological analysis was conducted using most probable number (MPN) of counting coliforms. The data generated were subjected to descriptive statistics and line graph. The analysis of the different groundwater resources revealed a good water quality but the values of $p H, T D S, E C, K$, were higher than the permissible range. The concentration of Fe and $\mathrm{Cr}$ is very high and could constitute some health hazards in some sources. The temporal variation of the water quality parameters did not follow any definite trend but the $\mathrm{pH}, \mathrm{NO}_{3}, \mathrm{TDS}, \mathrm{HCO}_{3}, \mathrm{SO}_{4}, \mathrm{Fe}, \mathrm{Cr}$ were highest in the dry months of April and December, while $\mathrm{Ca}, \mathrm{Mg}, \mathrm{K}, \mathrm{Na}$, hardness, and alkalinity were highest in the rainy months of June and August. The percentage of microbial distribution was highest in the months of June in the boreholes and the spring but the distribution in the dugwells was entirely different. The water from the boreholes and dugwells were generally soft and should be checked for plumbo-solvency. It is recommended that a routine monitoring of all the sources should be carried out and a treatment that will reduce the heavy metals concentrations be enforced.
\end{abstract}

Keywords: Groundwater resources, physico-chemical parameters, temporal variations, dugwells, boreholes and spring.

\section{INTRODUCTION}

Drinking water is generally obtained from two principal natural sources which are surface water such as fresh water lakes, rivers, streams and groundwater such as borehole, dugwells, springs and infiltration galleries [1]. Around the world, groundwater became a preferred source of drinking water because of its convenience, availability and good quality. The demand for groundwater is increasing in Nigeria because of the dwindling supply of pipe borne water especially in urban areas where population growth kept increasing. Contrary to the widely held theoretical view of groundwater being the safest and better water for consumption, some wells are found to be polluted in terms of temperature, mineral contents, heavy metals, organic matter and bacterial concentration [2]. Groundwater is derived from precipitation and from surface water bodies

* Corresponding author, tel: +234 - $803-453-9764$ 
such as lakes and streams that soak into the bed rock and stored in tiny spaces between rocks and particles of soil. Most times, naturally occurring substances are dissolved or suspended as fine grained solids in groundwater and in many cases, some water treatment is necessary before groundwater becomes acceptable for drinking purposes. The extraction of ground water is mainly by dug wells, drilled wells, boreholes while ground water that flows naturally from the ground is called a spring. Dug well is a shallow excavation up to about $10 \mathrm{~m}$ deep that penetrates an unconfined aquifer. Dug wells are not dependable source of water because of the seasonal variation in the depth of the water table and the well susceptibility to pollution [3]. Deep wells are those that are more than $30 \mathrm{~m}$ deep, and are mostly commonly used for public water supplies. The composition of groundwater is used to determine its potability and serves as a tool to determine the sources of naturally occurring and human related contaminants. The chemical parameters of groundwater play a significant role in classifying and assessing water quality. Season is believed to influence the concentration level of the physicochemical and bacteriological loading in water sources. Agbaire and Oyibo [4] reported that concentration of dissolved solids were low in the dry season. Ocheri, et al [5] found out that $80 \%$ of the wells had nitrate concentrations above the WHO allowable limit for drinking water for wet season. Egbulem [6] reported that $\mathrm{pH}$, total dissolved solids, total alkalinity, potassium, iron, sulphate have higher concentration in wet season, and temperature, turbidity, total hardness, chloride, magnesium, electrical conductivity, sodium, nitrate have higher concentrations in the dry season. Ishaka and Ezeigbo [7] studied some hand-dugwells and found out that wells were all contaminated, and that bacterial loadings increases from dry season to rainy season between 1998-2002. In Jemeta area of Yola town, [8] found concentrations of chloride, nitrate, total dissolved solids and coliform to far exceed the WHO allowable limit for drinking water in the wet season. The present study is to investigate the effect of time and season on the quality of the different groundwater resources in Ilesa West Local Government.

\section{MATERIALS AND METHODS}

\subsection{Study Area}

The study was conducted in Ilesa West Local Government Area (LGA) in Osun State, South Western Nigeria (Figure 1) from September 2016 to August 2017. Geographically, it is located within coordinates $07^{\circ} 36^{\prime} \mathrm{N}$ and $004^{\circ} 40^{\prime} \mathrm{E}$ and $07^{\circ} 42^{\prime} \mathrm{N}$ and $004^{\circ} 46^{\prime} \mathrm{E}$ and has a total area of $63 \mathrm{~km}^{2}$. The LGA belongs to a humid tropical type with humidity throughout the year and a mean annual rainfall of $1600 \mathrm{~mm} /$ year. It has two dominant seasons; a rainy season which is usually between May and October and a dry season from November to April. Geologically, the study area is within the basement complex of the crystalline rocks of Nigeria and it is underlained by mainly biotite-gneisis schist and amphibolites complex [9].

\subsection{Sample Collection and Analysis}

Water samples were collected from 63 dugwells, 5 boreholes and 1 spring (Table 1 ) for one year. The water points (Figure 2 ) were selected to cover all the 10 wards of the local government area and to show a fair representation of authority managing it including individually owned, privately owned and community. For the dugwells, well depths and water level were measured with a solinst water level meter at each sampling period. Water samples were taking from standpipes of boreholes and some wells while those without any were taken using bucket drawals. Water samples were collected in 2.5 litre plastic bottles that have been prewashed and rinsed with the sample water prior to sampling. After sampling, water samples were kept in ice packed containers and transported to laboratory for analysis. The $\mathrm{pH}$,TDS and temperature were measured onsite- using multipurpose portable $\mathrm{pH}$ meter. Parameters analysed in the laboratory were sulphate, nitrate, chloride, calcium, magnesium, hardness and alkalinity and bicarbonate. Sulphate was analysed using Turbidimetric method [10]; nitrate was analysed using Brucine method; chloride was analysed by using mercury (II) nitrate; calcium, magnesium and hardness were analysed using titrimetric method. Other cations ( $\mathrm{Na}, \mathrm{K})$ and heavy metals were analysed using AAS and microbiological analysis was performed with MPN method of counting coliforms The data generated were subjected to statistical analysis (descriptive, ) using SPSS and Excel sheet. 


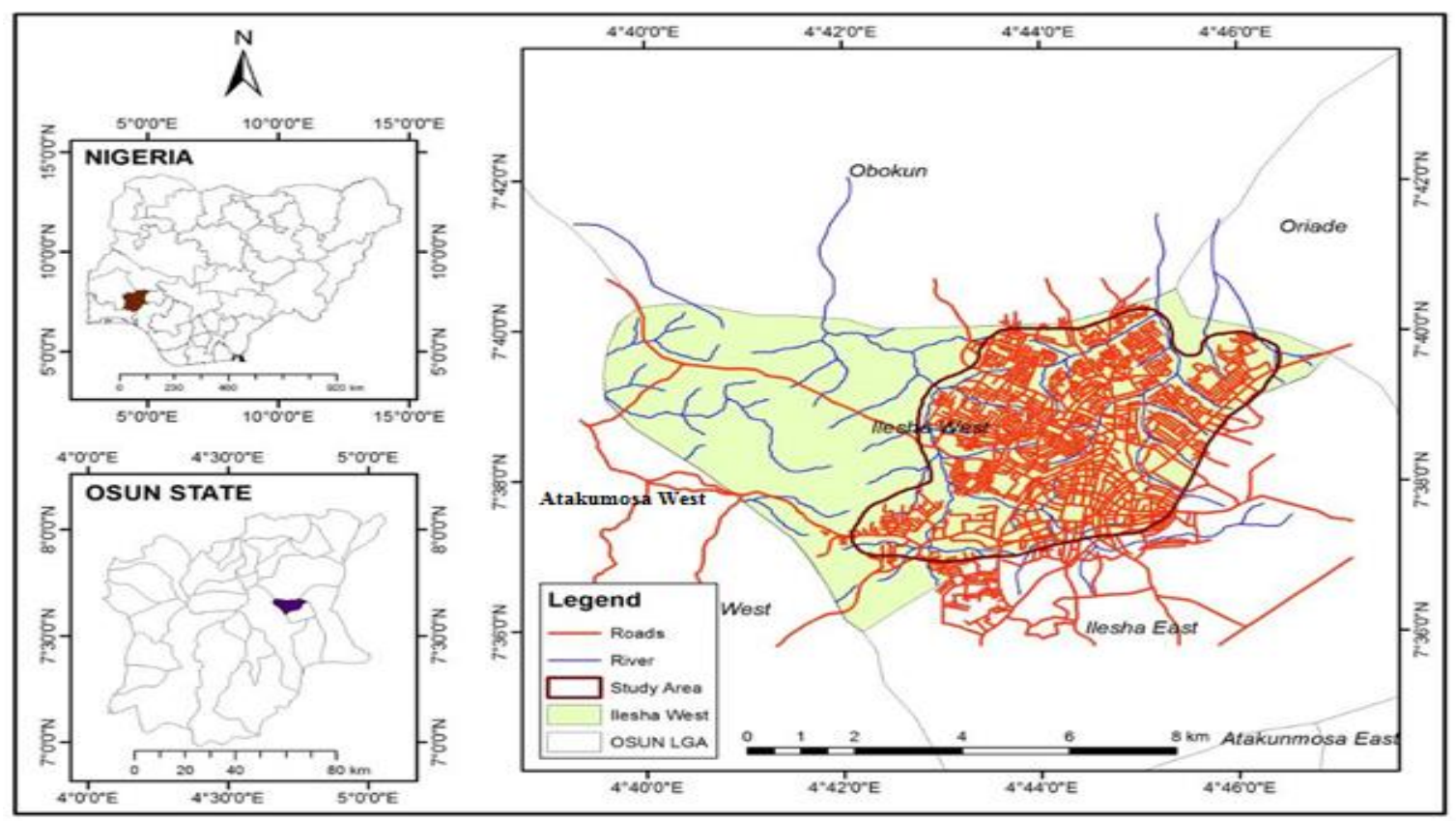

Fig. 1: Map of the study area

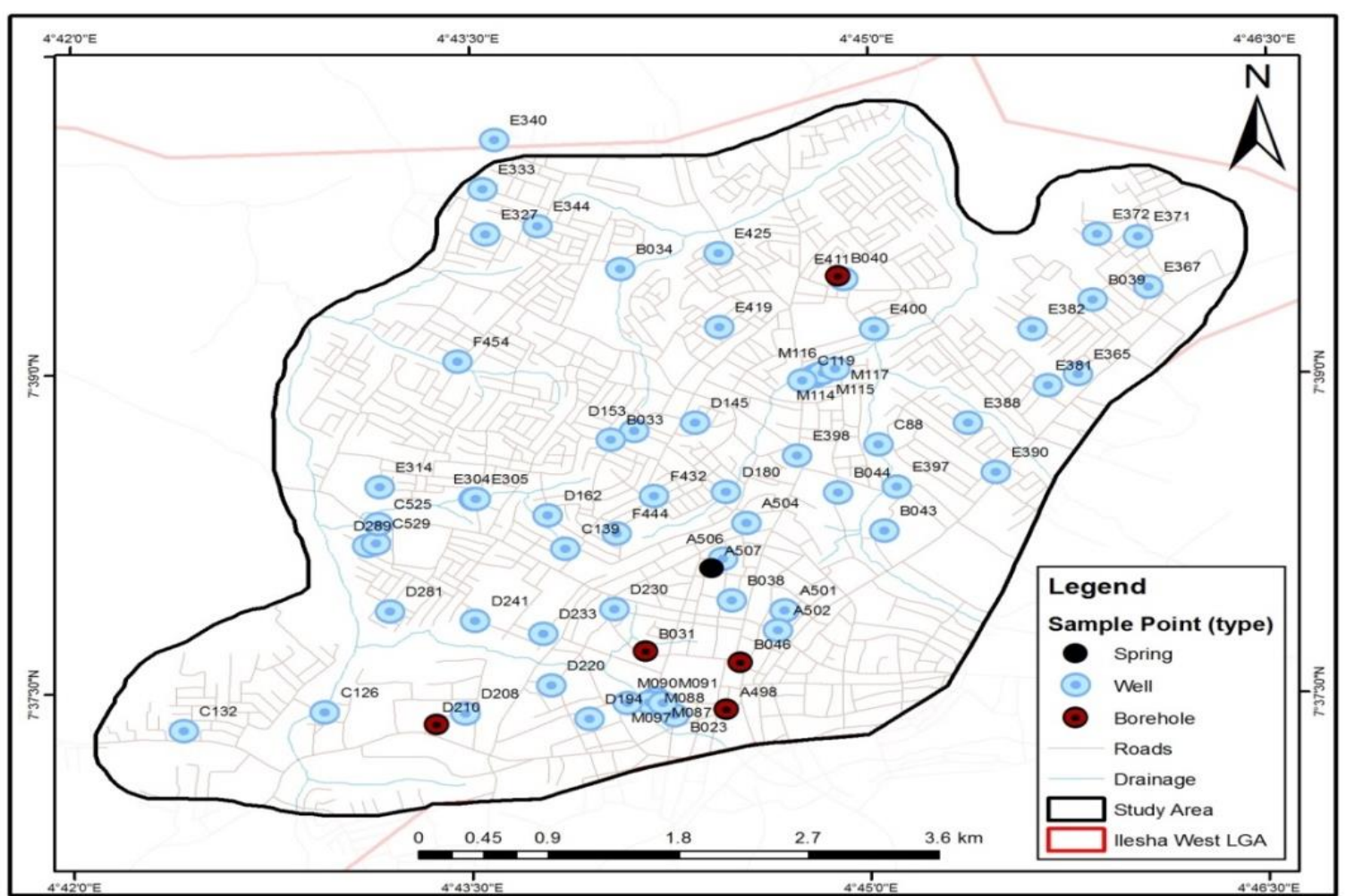

Fig. 2: Map of the sampling points in the study area

Table 1: Water points and street names

\begin{tabular}{|c|c|c|c|c|c|c|c|c|c|c|c|}
\hline \multicolumn{6}{|c|}{ Table 1: Water points and street names } & \multirow{2}{*}{$\begin{array}{l}\mathbf{S} / \\
\mathbf{N}\end{array}$} & \multirow{2}{*}{$\begin{array}{l}\text { Map } \\
\text { no }\end{array}$} & \multirow{2}{*}{$\begin{array}{l}\text { Elevati } \\
\text { on }(m)\end{array}$} & \multirow{2}{*}{$\begin{array}{l}\text { North } \\
\text { ern }\end{array}$} & \multirow{2}{*}{$\begin{array}{l}\text { Easter } \\
\text { n }\end{array}$} & \multirow{2}{*}{ Street name } \\
\hline S/ & Map & & North & Easter & Street name & & & & & & \\
\hline $\mathbf{N}$ & no & & e & & street name & 3 & A506 & 400 & 692024 & 844390 & Igbogi \\
\hline 1 & D194 & 375 & 691099 & 843001 & & 4 & B038 & 396 & 692089 & 844027 & Olomukogun \\
\hline 2 & D230 & 387 & 691273 & 843952 & Oromu & 5 & B046 & 387 & 692150 & 843490 & Adeti \\
\hline & & & & & & 6 & A498 & 389 & 692052 & 843081 & Itabalogun \\
\hline
\end{tabular}




\begin{tabular}{|c|c|c|c|c|c|c|c|c|c|c|c|}
\hline $\begin{array}{l}\mathbf{S} / \\
\mathbf{N}\end{array}$ & $\begin{array}{l}\text { Map } \\
\text { no }\end{array}$ & $\begin{array}{l}\text { Elevati } \\
\text { on }(m)\end{array}$ & $\begin{array}{l}\text { North } \\
\text { ern }\end{array}$ & $\begin{array}{l}\text { Easter } \\
\mathrm{n}\end{array}$ & Street name & $\begin{array}{l}\mathbf{S} / \\
\mathbf{N}\end{array}$ & $\begin{array}{l}\text { Map } \\
\text { no }\end{array}$ & $\begin{array}{l}\text { Elevati } \\
\text { on }(m)\end{array}$ & $\begin{array}{l}\text { North } \\
\text { ern }\end{array}$ & $\begin{array}{l}\text { Easter } \\
\text { n }\end{array}$ & Street name \\
\hline 7 & B023 & 376 & 691688 & 843033 & Odoiro & 46 & D281 & 370 & 689717 & 843933 & Awolodu, \\
\hline 8 & E344 & 391 & 690742 & 847272 & Arimoro & 47 & - & 402 & 691250 & 845571 & muroko \\
\hline 9 & E340 & 377 & 690441 & 848018 & Arimoro & 47 & Bus3 & 402 & 091250 & $8435 / 1$ & madim, ilaje \\
\hline 10 & E333 & 383 & 690358 & 847589 & Arimoro & 48 & D145 & 391 & 691832 & 845571 & Onala \\
\hline 11 & E327 & 390 & 690379 & 847201 & Arimoro & 49 & F454 & 373 & 690186 & 846096 & $\begin{array}{l}\text { Testing } \\
\text { ground }\end{array}$ \\
\hline 12 & D233 & 378 & 690779 & 843739 & Ikoyi & & & & & & osogbo road \\
\hline 13 & D241 & 368 & 690310 & 843849 & Ikoyi & 50 & D180 & 378 & 692046 & 844967 & Irebami, ilaje \\
\hline 14 & C139 & 394 & 690933 & 844474 & Ilaje & 51 & M114 & 369 & 692667 & 845976 & Ibala, mech 1 \\
\hline 15 & D162 & 382 & 690812 & 844767 & Seyitewo, ilaje & 52 & M115 & 358 & 692703 & 845995 & Ibala,mech 2 \\
\hline 16 & F432 & 393 & 691550 & 844932 & Irebamiilaje & 53 & M116 & 366 & 692719 & 846001 & Ibala, mech 3 \\
\hline 17 & F444 & 386 & 691289 & $\begin{array}{l}844609 \\
845496\end{array}$ & $\begin{array}{l}\text { Ilaje } \\
\text { Conebo ilaie }\end{array}$ & 54 & M117 & 371 & 692803 & 846035 & Ibala mech 4 \\
\hline 18 & D153 & 391 & 691412 & 845496 & Copebo, ilaje & & & & & & Araromi, \\
\hline 19 & D289 & 374 & 689561 & 844499 & isale general & 55 & M097 & 344 & 691556 & 843177 & junction (D1) \\
\hline 20 & C529 & 375 & 689622 & 844521 & isale general & 56 & M087 & 384 & 691566 & 843141 & Araromi, \\
\hline 21 & C525 & 373 & 689636 & 844691 & isale general & & & & & & $\begin{array}{l}\text { aumpsite, } \\
\text { Araromi, }\end{array}$ \\
\hline 22 & E304 & 370 & 690300 & 844908 & $\begin{array}{l}\text { Bello street, } \\
\text { ilaje }\end{array}$ & 57 & M088 & 371 & 691512 & 843142 & dumpsite 3 \\
\hline 23 & E305 & 371 & 690314 & 844908 & $\begin{array}{l}\text { Bello street, } \\
\text { ilaje }\end{array}$ & 58 & M090 & 380 & 691364 & 843141 & ite 4 \\
\hline 24 & E314 & 381 & 689646 & 845012 & $\begin{array}{l}\text { Along esoemi, } \\
\text { ilaje }\end{array}$ & 59 & M091 & 382 & 691610 & 843138 & $\begin{array}{l}\text { Araromi, } \\
\text { dumpsite } 5\end{array}$ \\
\hline 25 & C132 & 393 & 688288 & 842894 & Arimoro & 60 & B040 & 362 & 692822 & 846840 & Sawmill alfa \\
\hline 26 & C126 & 376 & 689267 & 843057 & Obeta & & E398 & 383 & 692541 & 845283 & Isokun \\
\hline 27 & D210 & 396 & 690044 & 842949 & $\begin{array}{l}\text { Beside high } \\
\text { court }\end{array}$ & 62 & E419 & 385 & 691999 & 846396 & $\begin{array}{l}\text { Along Apostollic } \\
\text { faith, ido-oko }\end{array}$ \\
\hline 28 & D208 & 400 & 690241 & 843046 & Along GRA & 63 & C119 & 371 & 692575 & 845937 & okeomiru \\
\hline 29 & E390 & 388 & 693915 & 845143 & $\begin{array}{l}\text { Bishop road, } \\
\text { coca-cola }\end{array}$ & 64 & C88 & 365 & 693103 & 845378 & Ibala \\
\hline 30 & E388 & 381 & 693723 & 845569 & $\begin{array}{l}\text { Oreofe, } \\
\text { cocacola }\end{array}$ & 65 & E343 & 380 & 691312 & 846902 & $\begin{array}{l}\text { Ajimoko along } \\
\text { fembest }\end{array}$ \\
\hline 31 & E381 & 374 & 694278 & 845894 & Obokun GCE & 66 & D220 & 376 & 690836 & 843292 & Kayanfada \\
\hline 32 & E365 & 376 & 694484 & 845992 & Along coca- & 67 & A502 & 395 & 692409 & 843770 & Ibosirin \\
\hline 33 & B039 & 381 & 694588 & 846635 & Iretiayo & 69 & A507 & 393 & 691951 & 844308 & Omi-oko \\
\hline
\end{tabular}

$34 \quad$ E371 382

$\begin{array}{lll}35 & \text { E372 } & 377\end{array}$

$\begin{array}{lll}36 & \mathrm{E} 367 \quad 390\end{array}$

$\begin{array}{lll}37 & E 397 \quad 384\end{array}$

$\begin{array}{lll}38 & \text { B044 } & 385\end{array}$

$\begin{array}{lll}39 & \text { B043 } 385\end{array}$

$40 \quad E 425 \quad 376$

$41 \quad E 411 \quad 374$

$42 \quad E 400 \quad 367$

$\begin{array}{lll}43 & \text { E382 } & 389\end{array}$

$\begin{array}{lll}44 & B 031 \quad 376\end{array}$

$45 \quad$ A501 390
$694900 \quad 847186$

$694620 \quad 847204$

694974846748

693232845016

692825844962

$693142 \quad 844634$

$691995 \quad 847038$

$692858 \quad 846813$

693074846382

$694170 \quad 846382$

$691490 \quad 843584$

692452843940
Theology, iretiayo

Imose, iretiayo

Adeyemi, iretiayo

Old omi-eran

Awolowo road

Agunrodo

Ido-oko road

Concord

Oke-omiiru

Babatope street

Araromi

Egbe-idi

\section{RESULTS AND DISCUSSION}

3.1. Descriptive Statistics

The mean $\mathrm{pH}$ (Table 2) of all the water resources showed that it is acidic and it is lower than WHO recommended (6.6- 8.5) values. The range however showed that some are within the alkaline regime except for the spring that was constantly acidic. A particular spring in general use by the residents was used for the study and the number might have introduced a bias in the result. The values of the $\mathrm{pH}$ agreed with the values obtained by [9] and [11] for dugwells in Ilesa urban which shows that the $\mathrm{pH}$ has not changed over time. There is a similar trend in the temporal variation (Figure 3a) for boreholes and spring as the highest was reported in April (dry 
season) while that in dugwells was reported in June which is a rainy month in the study area. Malomo, et al [9] attributed the low pH to little or no dissolved carbonate and hydroxyl ions i.e, presence of free carbon dioxide and dissolved inorganic carbon exists almost entirely as bicarbonates ions. The mean TDS of water samples (Table 2) showed that groundwater in the study area was less fairly mineralized however; some ranges revealed concentrations well above the recommended limits of $500 \mathrm{mg} / \mathrm{L}$. The temporal variation in TDS (Figure 3b) of the dugwells did not vary significantly but that of the boreholes and spring fluctuated. The highest mean for boreholes was recorded in December (dry season) and that was when the lowest was recorded in the spring. Difference in the TDS of the water sources could be attributed to the hydraulics of the sources. Water taken from dug wells are from storage and could be influenced by settlement while water taken from boreholes are under pressure and flows from a large area of influence; suggesting the reason for the high TDS at the dry months of December. Groundwater with long residence times has higher TDS because longer residence times result in more interaction between groundwater and soluble minerals The mean EC values for the water sources were generally low (Table 2); the maximum value reported is $1625 \mu \mathrm{S} / \mathrm{cm}$. The values of EC for the study area showed a constant trend for the period of assessment but there was wide disparity among the locations. The temporal variation in EC (Figure 3c) is a direct reflection of the TDS values. The mean value (Table 2 ) of $\mathrm{Cl}$ revealed that none of the samples exceeded the [12] maximum permissible level of $250 \mathrm{mg} / \mathrm{L}$ but a dug well around the vicinity of a dumpsite (M091) with $\mathrm{Cl}$ value of $212.70 \mathrm{mg} / \mathrm{L}$ exceeded highest desirable limit of 200 $\mathrm{mg} / \mathrm{L}$. There was an irregular pattern in the teemporal behavior of chloride (Figure 3d) as it may be expected that the concentration should be higher during the rainy season due to runoff into wells; there is a drop in $\mathrm{Cl}$ concentration in the dry month of December in the spring and the dugwells but a rise in the boreholes and this can be attributed to the residence time in water from boreholes. The mean concentration of nitrate (Table 2) was generally low. The highest mean value $(1.69 \mathrm{mg} / \mathrm{L})$ is reported in the borehole situated at commercial centre of the area. [9] reported nitrate values of $0-550 \mathrm{mg} / \mathrm{L}$ with $50 \%$ having nitrate above $50 \mathrm{mg} / \mathrm{L}$ in Ilesa shallow wells. The wide gap between the concentration in this study and that from [9] suggested an improved sanitation over the years and/or the decrease in agricultural practices to the outskirts of the area. Temporal variation of nitrate (Figure 3e) revealed the highest mean in the boreholes in the dry month of April. The mean concentrations of sulphate (Table 2 ) showed a general decline. The low level of sulphate could be as a result of microbial action capable of reducing $\mathrm{SO}_{4}{ }^{2}-$ to $\mathrm{S}$ leading to depletion of sulphate [13]. There is no apparent depth related trend in sulphate concentration since it varied between boreholes and wells. In contrast to the nitrate variation, the mean concentration was highest in the spring in the month of April as shown in Figure 3f. This suggested a possible runoff of early rain into the spring as the location of the spring is on lowlands and around a drainage in the study area. The mean concentrations of bicarbonates were higher in the boreholes and spring than in the dugwells but the maximum concentration was recorded in the dugwells. Bicarbonate concentrations in the area were below the WHO limit of $500 \mathrm{mg} / \mathrm{L}$.

The temporal variation of bicarbonates is presented in Figure 3g. There is an irregular trend in the pattern, highest was reported in December (dry season) and June (beginning of heavy rain). The mean concentration of calcium (Table 2) in boreholes and spring was slightly higher than that of the dugwells and this suggested that there were more abundance of calcium rich rocks in the aquifer than in the ground. The presence in dugwells might be due to acidic rainwater leaching the calcium from soils. The variation in $\mathrm{Ca}$ (Figure 4a) fluctuated with similar trends in the water sources and the value was highest in the month of August. This suggested dissolution of calcium containing rocks in the aquifer. The mean concentration of magnesium (Table 2) was different from that of calcium as the highest was reported in the spring. The number of spring analysed might have introduced the biased result. The values of magnesium were generally low in all the water samples while the highest concentration was obtained in the borehole. The pattern of variation of magnesium (Figure $4 b$ ) was irregular and the highest was reported in the spring in the month of August (rainy month). The mean concentration of sodium $(23.75 \mathrm{mg} / \mathrm{L})$ in the boreholes was higher than the dugwells but the range in the two water sources was the same (Table 2). The temporal pattern of sodium (Figure 4c) in the dugwells and boreholes was different and this suggested a different flow regime in the two water sources. The mean concentration of potassium $(20.78 \mathrm{mg} / \mathrm{L})$ was higher 
in boreholes than values in the dugwells but the range in dugwells was higher (Table 2) than values in the boreholes and springs.

Generally there was a large variation from points to points. The maximum desirable is $100 \mathrm{mg} / \mathrm{L}$ [13] but the maximum allowed limits by NAFDAC is $10 \mathrm{mg} / \mathrm{L}$ [15]. The excess amount of potassium present in the water sample may lead to nervous and digestive disorder [16]. The values obtained agreed with values of [9] and this suggested that the concentration of the cations in Ilesa has not changed. The variation of $\mathrm{K}$ (Figure 4d) showed that dissolution of $\mathrm{K}$ in the water sources was entirely different but the highest were reported in the rainy months of September and June. The range of hardness (Table 2) in the dugwells was substantially high. The primary components of hardness are calcium $\left(\mathrm{Ca}^{2+}\right)$ and magnesium $\left(\mathrm{Mg}^{2+}\right)$ ions. A total of $69 \%$ of the water samples fell below $50 \mathrm{mg} / \mathrm{l}$ and $48 \%$ fell below $30 \mathrm{mg} / \mathrm{L}$ so the water in the study area is generally soft. It has been proposed that soft waters with hardness less than $100 \mathrm{mg} / \mathrm{L}$ are more corrosive for water pipes because of their low buffer capacity. This is also true for low $\mathrm{pH}$ values. Water softer than $30-50 \mathrm{mg} / \mathrm{L}$ tend to be corrosive and should be examined for plumbo-solvency [17]. The temporal variation of hardness (Figure 4e) followed a regular pattern like that of calcium (the highest values were reported in August) suggesting that the hardness in the water samples were mainly due to calcium ions.

The mean concentrations of alkalinity were higher in boreholes and spring (Table 2) than in dugwells. Most times total alkalinity is due to carbonates and hydroxides of calcium, magnesium, potassium and sodium. There was a constant pattern of concentration of alkalinity and majority occurred in well points with higher $\mathrm{pH}$. The alkalinity may be attributed to or be said to be influenced by the underlying geology. The temporal pattern of alkalinity (Figure 4f) almost flattens out in the dugwells while it fluctuated reasonably at the boreholes but the highest were reported in the rainy months of September and June . The mean concentration $(1.32 \mathrm{mg} / \mathrm{L})$ of $\mathrm{Fe}$ in the dugwells is higher than the permissible values of 0.3 $\mathrm{mg} / \mathrm{L}$. Iron occurs naturally in soils and rocks and in aquifer, groundwater comes in contact with this solid material, thereby dissolving them. Usually iron is less than $0.5 \mathrm{mg} / \mathrm{L}$ in fully aerated water while groundwater with $\mathrm{pH}$ less than 8 can contains 10 $\mathrm{mg} / \mathrm{L}$; infrequently, $50 \mathrm{mg} / \mathrm{L}$ may be present. The mean values for the different water sources are higher than $0.3 \mathrm{mg} / \mathrm{L}$ permissible limit. The temporal variation (Figure $4 \mathrm{~g}$ ) revealed a common trend as the highest was reported in the dry month of Dec and April for the dugwells/boreholes and spring respectively. The mean concentration of $\mathrm{Cr}$ in the dugwells is $0.23 \mathrm{mg} / \mathrm{L}$ and $0.24 \mathrm{mg} / \mathrm{L}$ in the boreholes. The values obtained are higher than the $0.05 \mathrm{mg} / \mathrm{L}$ permissible limit. The temporal variation of $\mathrm{Cr}$ (Figure $4 \mathrm{~h}$ ) show that the borehole has the highest in the month of August followed by the dugwells while the spring has the highest in the month of April.

The seasonal variation of the microbial distribution showed that E.coli has the highest number of occurrence $(53 \%)$ in the dry month of December (Figure 5) in the dugwells. The high percentage in the dry month might be due to higher survival rate of the micro-organisms and the status of the well in terms of construction and withdrawal technology. The percentage of E.coli in the boreholes is $20 \%$; the construction of boreholes is different from that of dugwells but bacteria could enter groundwater through many interacting variables related to land use, soil types, depth to water, types of geologic strata and method of construction [18]. Another factor affecting maximum survival of coliform bacterial in groundwater is warm moist condition. The percentage of occurrence (44.4\%) in September in the dugwells (Figure 5) could be associated with the period being a raining season, ruuoff could have influenced. The drop in occurrence observed in February and April (Figure 5) was expected as the months were in the period of dry season and infiltration from runoff would have seized. The jump in occurrence in the rainy month of June (Figure 5) was an indication that the occurrence of microorganisms in the groundwater sources in the study area has seasonal imprint.

\section{Table 2: Mean concentration, standard error and range of physico-chemical parameters}

\begin{tabular}{llll}
\hline Parameter & Dug - wells & Boreholes & Spring \\
\hline pH(no unit) & $5.60 \pm 0.76(4.1-7.4)$ & $5.93 \pm 0.78(4.4-7.3)$ & $6.01 \pm 0.10(5.9-6.2)$ \\
WT $\left({ }^{\circ} \mathrm{c}\right)$ & $27.98 \pm 3.73(25.0-34.0)$ & $27.66 \pm 1.28(26.0-31.1)$ & $27.92 \pm 0.86$ \\
DW $(\mathrm{m})$ & $7.91 \pm 3.73(2.00-15.40)$ & NM & NM \\
DTWL $(m)$ & $6.15 \pm 3.39(0.46-14.02)$ & NM & NM
\end{tabular}




\begin{tabular}{llll}
\hline Parameter & Dug -wells & Boreholes & Spring \\
\hline $\mathrm{TDS}(\mathrm{mg} / \mathrm{L})$ & $165.29 \pm 204.75(8.30-$ & $280.45 \pm 234.15(13.30-737)$ & $276 \pm 81.99(202-408)$ \\
& $1022.00)$ & $466.11 \pm 409.77(15.54-$ & $444.33 \pm 162.09(231-620)$ \\
$\mathrm{EC}(\mu \mathrm{S} / \mathrm{cm})$ & $262.99 \pm 331.34(12.34-1625)$ & $1474)$ & \\
$\mathrm{Cl}(\mathrm{mg} / \mathrm{L})$ & $28.17 \pm 37.21(1.40-212.70)$ & $36.87 \pm 33.04(2.22-106.49)$ & $66.63 \pm 26.23(14.21-84.37)$ \\
$\mathrm{SO}_{4}(\mathrm{mg} / \mathrm{L})$ & $10.97 \pm 7.66(1.28-33.76)$ & $13.21 \pm 8.02(1.28-28.52)$ & $13.10 \pm 6.47(9.66-26.07)$ \\
$\mathrm{NO}_{3}(\mathrm{mg} / \mathrm{L})$ & $1.35 \pm 1.55(0.07-8.68)$ & $1.69 \pm 2.21(0.10-9.21)$ & $0.81 \pm 0.63(0.10-1.98)$ \\
$\mathrm{Ca}(\mathrm{mg} / \mathrm{l})$ & $16.77 \pm 19.10(1.66-132.29)$ & $36.94 \pm 30.76(2.40-82.11)$ & $25.42 \pm 3.80(20.23-28.23$ \\
$\mathrm{Mg}(\mathrm{mg} / \mathrm{L})$ & $1.85 \pm 1.83(0.00-1.83)$ & $1.47 \pm 1.65(0.13-7.35)$ & $2.27 \pm 2.06(0.13-5.72)$ \\
$\mathrm{TH}(\mathrm{mg} / \mathrm{L})$ & $50.60 \pm 48.19(6.50-330.15)$ & $98.42 \pm 73.79(9.39-220.00)$ & $71.92 \pm 13.391(57.23-$ \\
$\mathrm{Alkalinity}$ & & $89.67 \pm 73.18(14.00-$ & $94.02)$ \\
$(\mathrm{mg} / \mathrm{L})$ & $42.84 \pm 48.40(4.00-260.00)$ & $210.00)$ & $63.33 \pm 2.73(60.00-66.00)$ \\
$\mathrm{HCO}(\mathrm{mg} / \mathrm{L})$ & $51.41 \pm 58.08(4.80-312.00)$ & $107.80 \pm 87.81(16.80-$ & \\
$\mathrm{CO}(\mathrm{mg} / \mathrm{L})$ & $25.70 \pm 29.04(2.40-186.00)$ & $53.00)$ & $76.00 \pm 3.28(72.00-79.20)$ \\
$\mathrm{Na}(\mathrm{mg} / \mathrm{L})$ & $23.67 \pm 24.55(0.98-107.50)$ & $23.75 \pm 24.10(0.98-107.50)$ & $33.00 \pm 1.64(36-39.60)$ \\
$\mathrm{K}(\mathrm{mg} / \mathrm{L})$ & $16.32 \pm 29.01(0.02-176.01)$ & $20.78 \pm 25.51(0.92-84.59)$ & $32.53 \pm 1.87(30.00-35.27)$ \\
\hline
\end{tabular}

WT: water temperature DW: depth of well

DTWL: depth to water level

NM: Not measured

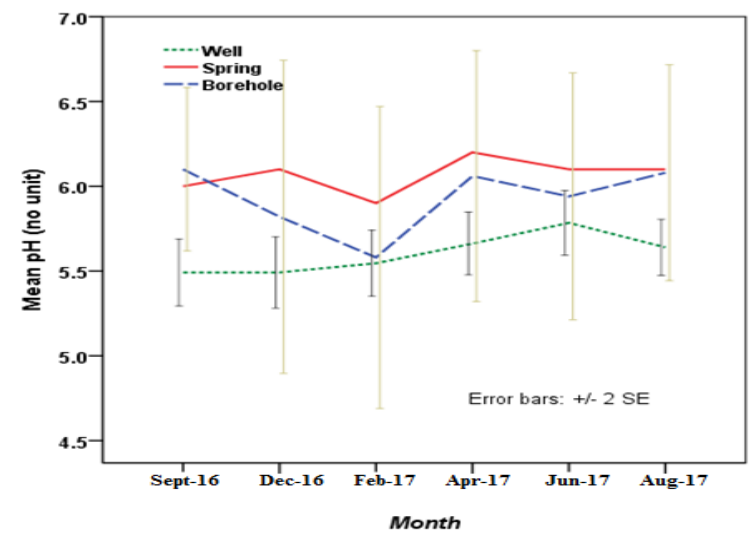

Figure 3a) Graph of Ph

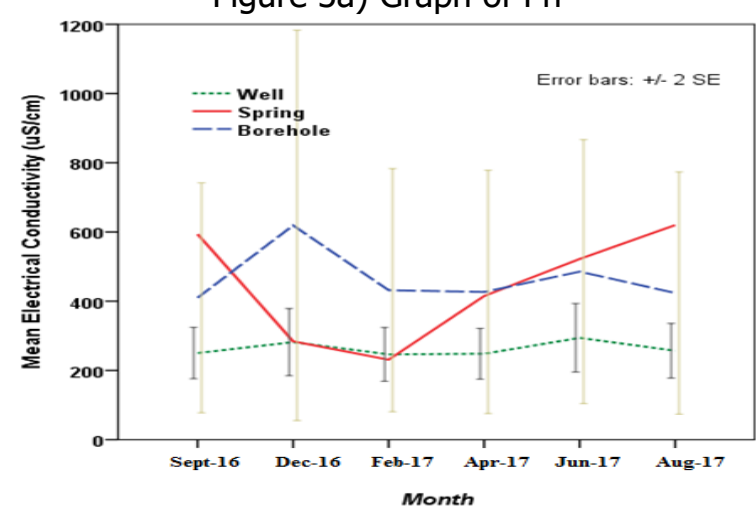

Figure 3c) Graph of TDS

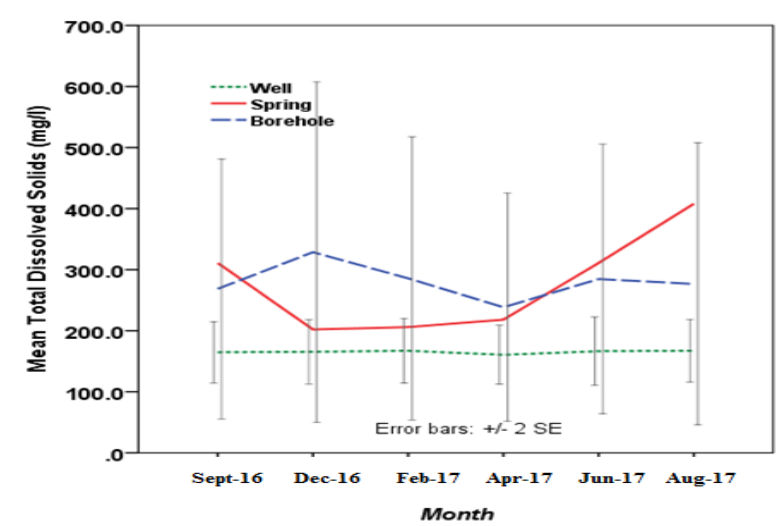

Figure 3b) Graph of EC

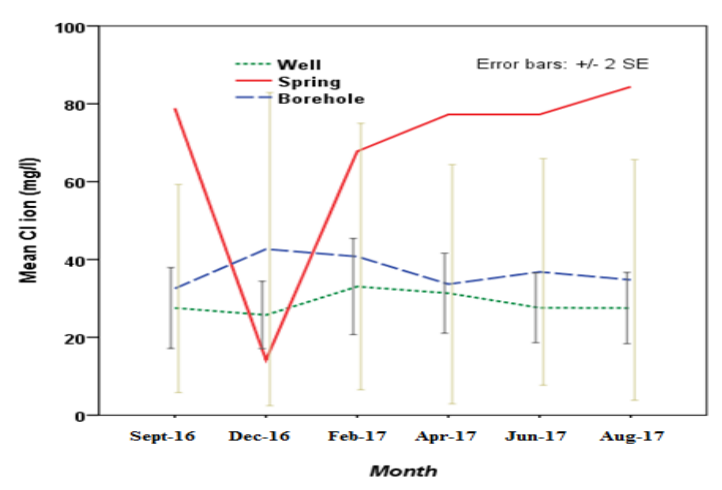

Figure 3d) Graph of $\mathrm{Cl}$ 


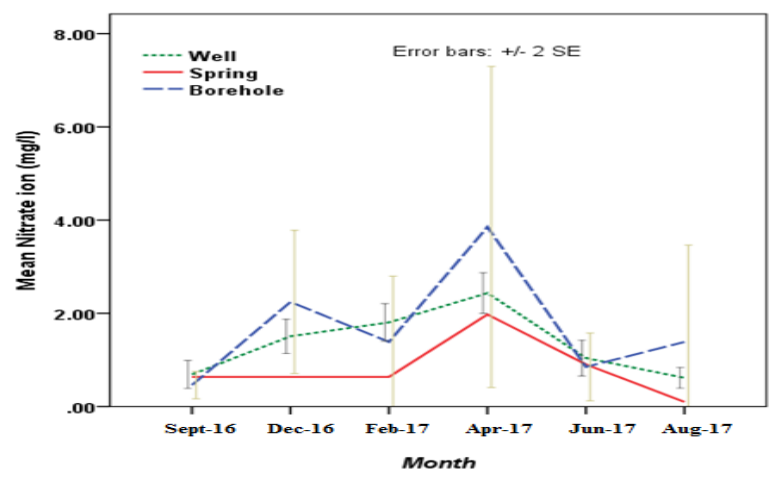

Figure 3e) Graph of Nitrate

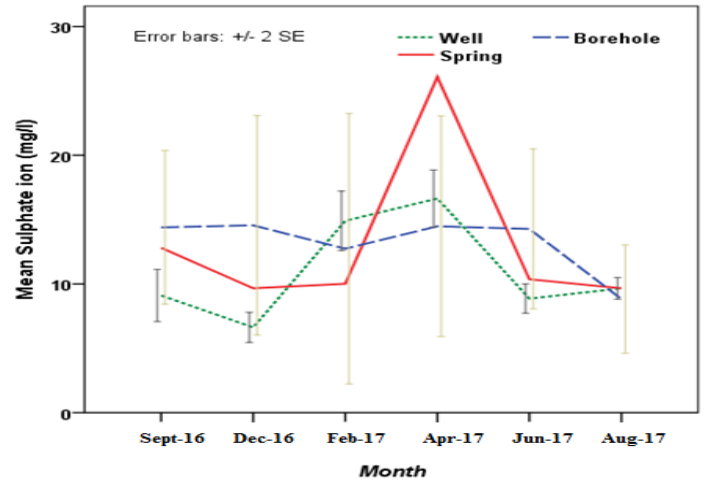

Figure 3f) Graph of sulphate

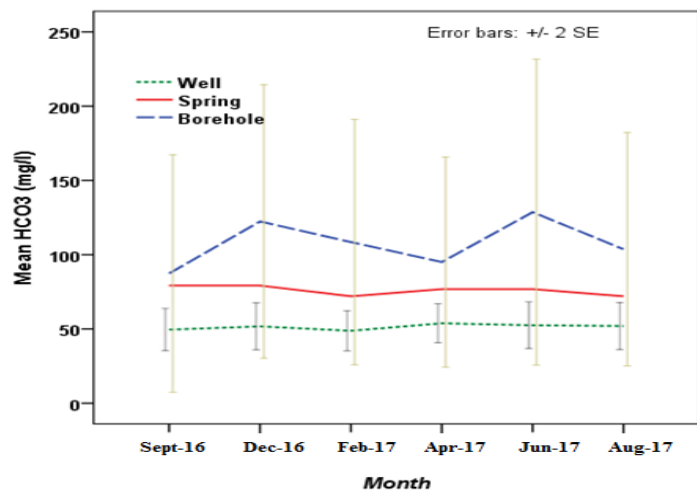

Figure 3g) Graph of Bicarbonate

Fig. 3: Temporal variation of groundwater parameters

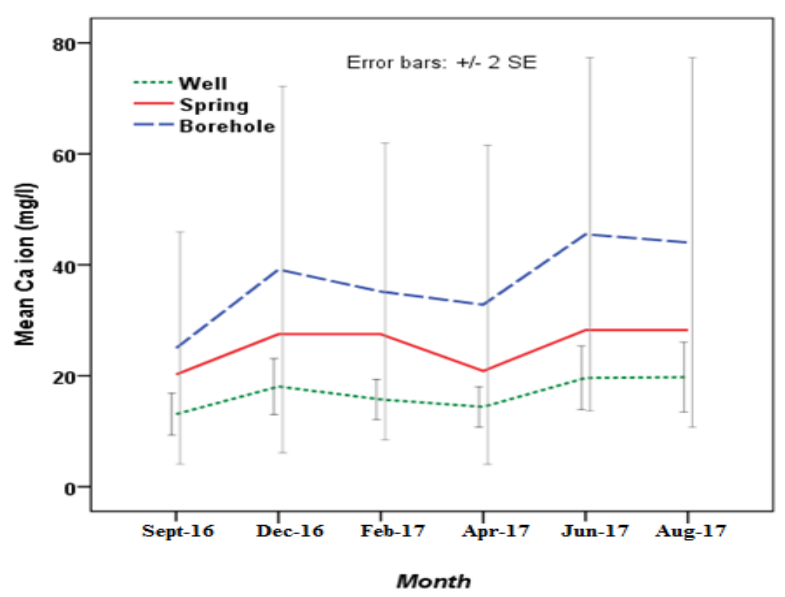

Figure 4a) Graph of Ca

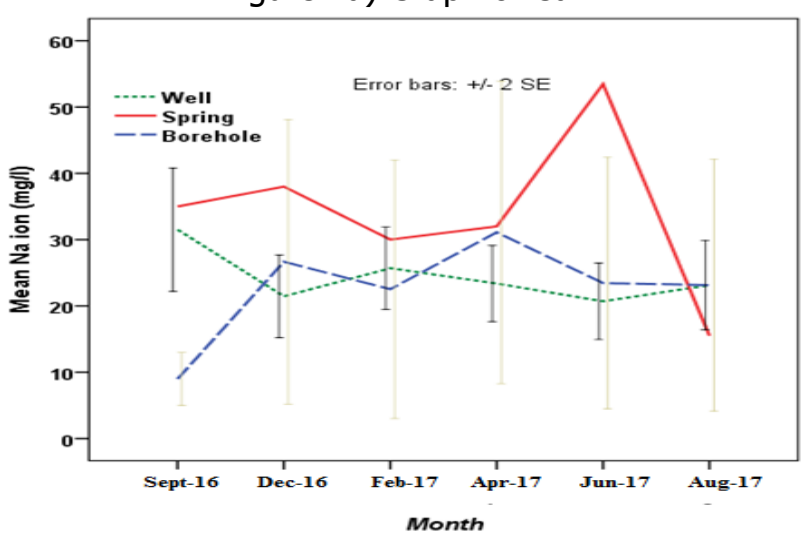

Figure 4c) Graph of $\mathrm{Na}$

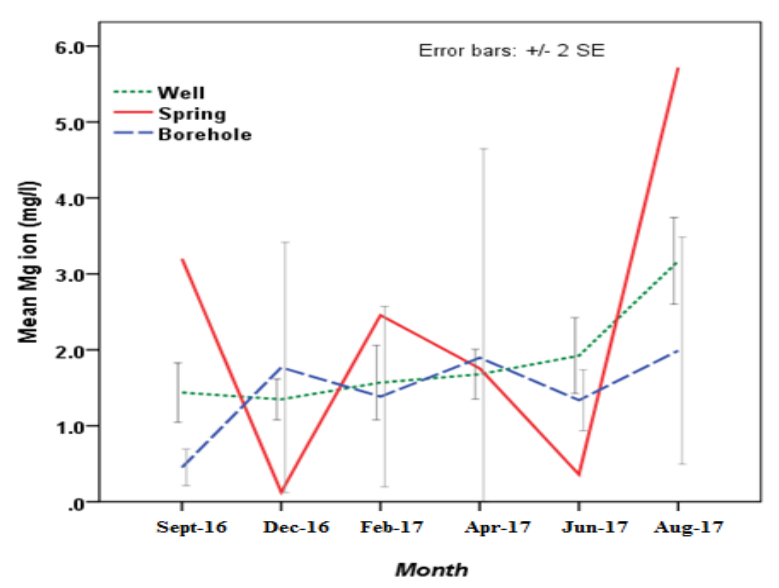

Figure 4b) Graph of Mg

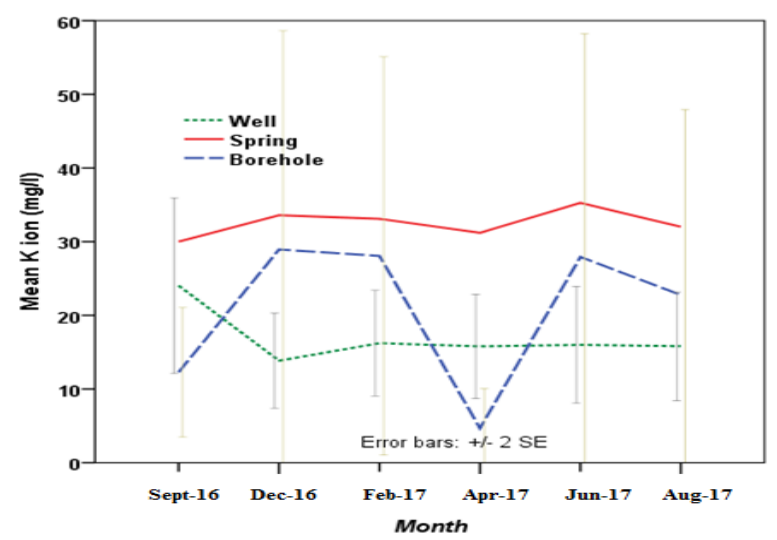

Figure 4d) Graph of K

Vol. 39, No. 1, January 2020 


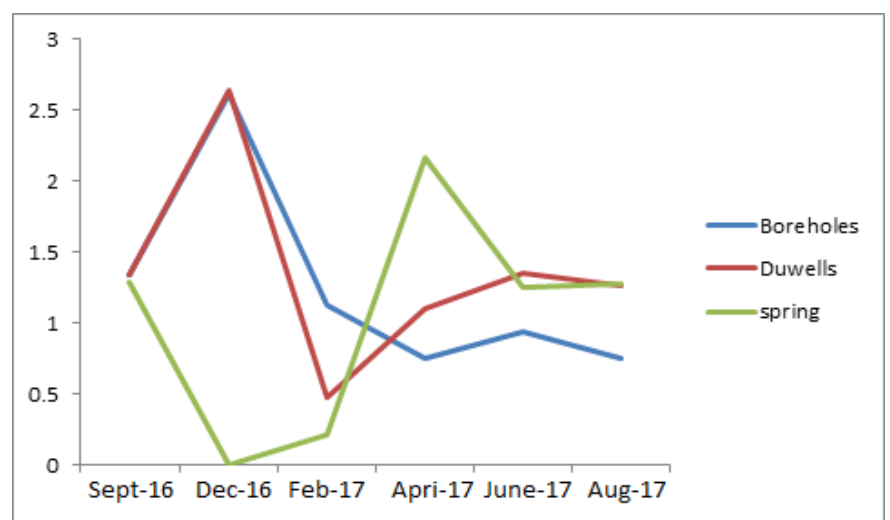

Figure 4g) Graph of Fe

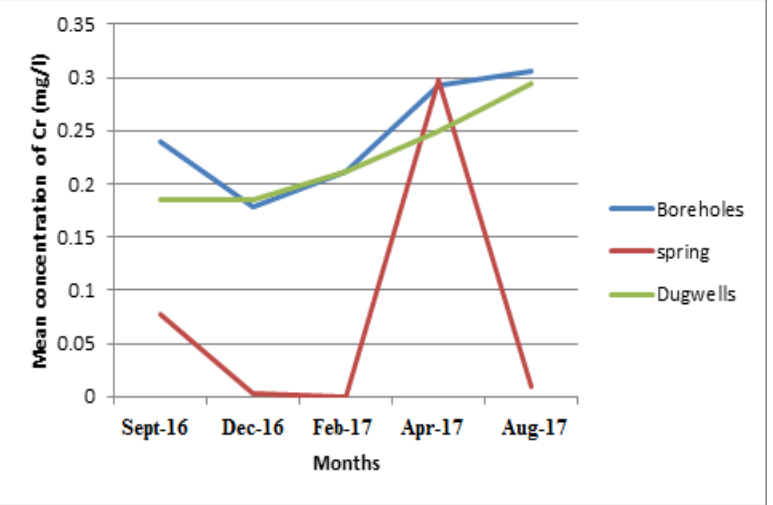

Figure 4h) Graph of $\mathrm{Cr}$

Fig. 4: Temporal variation of groundwater parameters

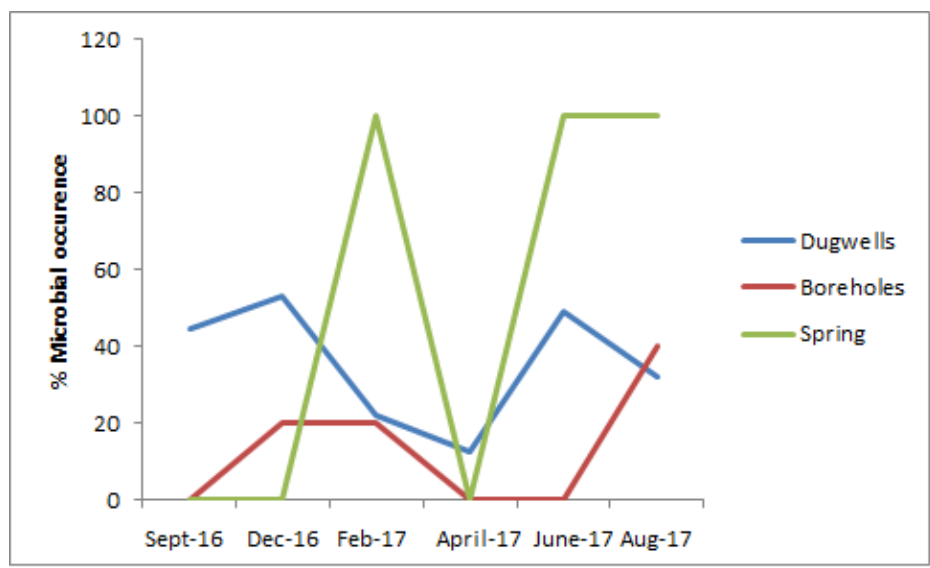

Fig. 5: Percentage of microbial occurrence

\section{CONCLUSION AND RECOMMEDATION}

The analysis of the different groundwater resources revealed a good water quality for all the seasons but the values of $\mathrm{pH}, \mathrm{TDS}, \mathrm{EC}, \mathrm{K}$, were higher than the permissible range. The concentration of $\mathrm{Fe}$ and $\mathrm{Cr}$ is very high and could constitute some health hazards in some sources. The temporal variation of the water quality parameters did not follow any definite trend but the $\mathrm{pH}, \mathrm{NO}_{3}, \mathrm{TDS}, \mathrm{HCO}_{3}, \mathrm{SO}_{4}, \mathrm{Fe}, \mathrm{Cr}$ were highest at the dry months of April and December, while Ca, $\mathrm{Mg}, \mathrm{K}, \mathrm{Na}$, hardness, and alkalinity were highest in the rainy months of June and August. The water from the boreholes and dugwells are generally soft and should be checked for plumbo-solvency. It is recommended that a routine monitoring of all the sources should be carried out and a treatment that will reduce the heavy metals concentrations be enforced.

\section{REFERENCES}

[1]. Mendie, U. (2005). The Nature of Water In: The Theory and Practice of Clean Water Production

Nigerian Journal of Technology, for Domestic and Industrial Use. Lacto-medal Publishers, Lagos, Nigeria. 1-21

[2]. Appelo, C. A. J., and Postma, D. (2005). Geochemistry of,Groundwater and Pollution, 2nd (edn), CRC Press, Taylor and Francis Group, Oxford, U.K.

[3]. Nathanson, J. A. (2000). Basic Environmental Technology. McGraw hill, Washington D.C, U.S.A.

[4]. Agbaire, P. O., and Oyibo, P. (2007). Seasonal Variation of some Physico-chemical Properties of Boreholes in Abraka, Nigeria. African Journal of Pure and Applied Chemistry.3 (6):116-118.

[5]. Ocheri, M.I., Odoma, L.A., and Umar. N.D. (2014). Groundwater Quality in Nigeria Urban Areas: A Review. Global Journal of Science Frontier Research: Environment and Earth Sciences. 14(3):35-44

[6]. Egbulem, B. N. (2003).Shallow Groundwater Monitoring. 29th International Conference Water Engineering and Development Centre (WEDC), Abuja, Nigeria. 133-134.

[7]. Ishaku, J. M., and Ezeigbo, H. I. (2010). Groundwater Quality Monitoring in Jemeta- 
Yola Area of Northeastern Nigeria. Journal of Water Resources, 20 (2):1-14.

[8]. Nwafor, E. K.,Okoye, C. J., and Akinbile, O. C. (2013). Seasonal Assessment of Groundwater Quality for Domestic Use in Akure Metropolis, Ondo State, Nigeria. Proceeding of Nigerian Association of Hydrological Sciences Conference on Water Resources and National Development in C (eds) :38-42.

[9]. Malomo, S., Okufarasin, V. A., Olorunnio, M. A. and Omode, A. A. (1990). Groundwater Chemistry of Weathered Zone Aquifers of an Area Underlain by Basement Complex Rocks. Journal of African Earth Sciences. II(3/4):357371

[10]. Ademoroti, C. M. O. (1996). Standard Methods for Water and Effluents Analysis. Foludex Press Ltd, Ibadan, Oyo State, Nigeria.

[11]. Ayoade, P. A., and Ibitoye, T. A. (2012). Appraisal of Water Quality Status Within Ilesa Environs, South Western Nigeria. Journal of Emerging Trends in Engineering and Applied Sciences. 3(6):969-976

[12]. WHO. (2004). Guidelines for Drinking Water Quality. 3(1):515.

[13]. WHO. (1997). Guidelines for Drinking Water: Recommendations. World Health Organization. Geneva, Switzerland
[14] Abdulrafiu, O., Majolagbe, A., Adeleke, A., Kasali, K., Lateef, .O and Ghaniyu, F. (2011). Quality Assessment of Groundwater in the Vicinity of Dumpsites in Ifo and Lagos, Southwestern Nigeria. Advances in Applied Science Research. 2(1): 289-298

[14]. Ufoegbune, G. C., Lamidi, K. I., Awomeso, J. A., Eruola, A. O., Idowu, O. A., and Adeofun, C. O. (2009). Hydrogeochemical Characteristics and Groundwater Quality

[15]. Tiwary, R. K. (2001). Environmental Impact of Coal Mining on Water Regime and its Management. Water, Air and Soil Pollution 132:185-199.

[16]. Adewoyin, O. A, Hassan, A. T and Aladesida, A. A (2013). The Impacts of Auto-Mechanic Workshops on Soil and Groundwater in Ibadan Metropolis. African Journal of Environmental Science and Technology. 1(9): 891-898

[17]. Somaratne, G., and Hallas G.(2015). Review of Risk Status of Groundwater Wells by Tracing the Source of Coliform Contamination. Water. 7:3878-3905. www.mdpi.com/journal/water. 